\title{
Serological ecology of Neisseria gonorrhoeae (PPNG and non-PPNG) strains: Canadian perspective
}

\author{
J R DILLON,* S M BYGDEMAN, $\uparrow$ AND E G SANDSTRÖM $\ddagger$ \\ From the *Laboratory Centre for Disease Control, Ottawa, Canada, $\dagger$ Huddinge University Hospital and \\ $\ddagger$ Södersjukhuset, Karolinska Institute, Stockholm, Sweden
}

SUMMARY One hundred and thirty eight penicillinase producing Neisseria gonorrhoeae (PPNG) and 239 non-PPNG strains were characterised serologically using a panel of seven monoclonal antibodies directed against protein 1A and seven against protein 1B. An association between serovar and susceptibility to antimicrobial agents, auxotype, and plasmid content was observed. Serogroup WI strains were more sensitive to penicillin, ampicillin, tetracycline, erythromycin, cefoxitin, and cefuroxime. Sixty five (82\%) of the 79 WI strains were typed as being serovar Aedgkih, and 47 $(72 \%)$ of these strains required arginine, uracil, and hypoxanthine for growth ( $\left.\mathrm{AUH}^{-}\right)$. Seventy one (44\%) of 160 WII/WIII strains were serovar Bacejk, and $42(59 \%)$ of these required proline, citrulline, and uracil for growth ( $\left.\mathrm{PCU}^{-}\right)$and were plasmid free. Serovars Bcgk, Beghjk, Bacjk, and Bajk were associated with resistance to antimicrobial agents. Analysis of PPNG isolates showed a new serovar, Af, which was associated with strains imported from Malaysia and Singapore that required proline and ornithine for growth $\left(\right.$ Pro $\left.^{-} \mathrm{Orn}^{-}\right)$and carried the 24.5 megadalton transfer plasmid, the 2.6 megadalton cryptic plasmid, and the 4.5 megadalton penicillinase producing plasmid. Other associations between serovar and geographical location were noted.

\section{Introduction}

Differentiation between strains of Neisseria gonorrhoeae for epidemiological and clinical purposes has been accomplished by using a combination of several techniques: auxotyping, ${ }^{2}$ plasmid content analysis, ${ }^{34}$ and restriction endonuclease analysis. ${ }^{5}$ In characterising strains by nutritional requirement (auxotype), differences have been noted between geographical area of isolation, race of patient, and clinical syndrome.$^{6-9}$ Correlation between auxotype and other phenotypes, such as plasmid carriage or susceptibility to antimicrobial agents has also been observed. ${ }^{41012}$ For example, isolates requiring arginine, hypoxanthine, and uracil for growth

This study was presented, in part, at the international conjoint sexually transmitted diseases meeting held on 17-21 June 1984 in Montreal, Canada.

\footnotetext{
Address for reprints: Dr J R Dillon, Antimicrobials \& Molecular Biology Division, Bureau of Microbiology, Laboratory Centre for Disease Control, Tunney's Pasture, Ottawa, Ontario K1A OL2, Canada

Accepted for publication 14 October 1986
}

$\left(\mathrm{AHU}^{-}\right)$tend to be sensitive to $\beta$ lactam antibiotics, ${ }^{6} 1011$ the proline, citrulline, uracil requiring $\left(\mathrm{PCU}^{-}\right)$auxotype is plasmid free, ${ }^{3}$ and the carriage of certain plasmids in penicillinase producing strains of $N$ gonorrhoeae (PPNG) has been associated with specific auxotypes. ${ }^{41112}$ These typing techniques have been invaluable in tracking microepidemics within countries as well as in monitoring the international dissemination of strains, particularly PPNG isolates. ${ }^{13-16}$

Serological methods based on the antigenic determinants of protein $1 \mathrm{~A}$ or $\mathrm{BB}$ have been used effectively to differentiate further between gonococcal strains.$^{17-19}$ Serological classification is carried out using a modification of the coagglutination technique developed by Kronvall. ${ }^{20}$ As a further refinement of the technique, which initially divided isolates into three groups using polyclonal antibodies, monoclonal antibodies directed against epitopes on protein 1 were produced, thereby further differentiating serogroups into serovars ?1-23 $^{21}$ Gonococcal serovars have also been shown to vary according to geographical source, auxotype, and susceptibility to antibiotics. ${ }^{24-26}$ The international analysis of these variables is still preliminary, as are 
data pertaining to the relation between serovar and plasmid content.

The present work was undertaken to explore, in the Canadian context, the relation between serovar and other variables such as auxotype, susceptibility to antimicrobials, and plasmid content.Non-PPNG and PPNG strains were serologically classified to ascertain their serological diversity and whether particular serovars were peculiar to specific regions.

\section{Materials and methods}

\section{STRAINS OF BACTERIA}

Non-PPNG strains were selected from the national collection (1973-84) of the antimicrobials and molecular biology division of the Laboratory Centre for Disease Control, Ottawa. They had been stored either by lyophilisation in $2 \%$ skimmed milk medium or by freezing $\left(\right.$ at $\left.-70^{\circ} \mathrm{C}\right)$ in growth medium containing $20 \%$ gycerol. ${ }^{27}$ The strains for testing were chosen to reflect the distribution of auxotypes seen in Canada ${ }^{11}$ and to represent most geographical regions in the country (33 strains from the Atlantic regions, 25 from the province of Quebec, 84 from Ontario, 13 from Manitoba and Saskatchewan, 43 from Alberta , and 40 from British Columbia). In addition, 138 PPNG strains, 114 of which had been isolated in Canada, 20 in Chile (from Dr J Garcia Moreno of Santiago), and four in Argentina (from Dr F Marcenac of Buenos Aires), were typed serologically.

\section{SEROLOGICAL CHARACTERISATION}

The strains were serologically characterised by coagglutination using monoclonal antibodies to protein 1 as described by Tam et $a l^{21}$ and Bygdeman et al. ${ }^{23}$ Isolates were identified as belonging to serogroups designated WI or WII/III. Serogroups were subdivided into different serovars using monoclonal antibodies specific for protein 1A or 1B (table I) ${ }^{21}$
Two different nomenclatures have been used to designate serovars in published reports, though almost identical panels of monoclonal antibodies have been used ${ }^{22}$ In the present study, all serovars beginning with A belonged to serogroup WI, whereas all beginning with B were serogroup WII/III. The present study also included several monoclonal antibodies (6G 9/Af, $5 \mathrm{C} 2 / \mathrm{Ak}, 2 \mathrm{H} 7 / \mathrm{Be}$, and $3 \mathrm{BI} 0 / \mathrm{Bj}$ ) that were not used in nomenculature published by Knapp et al.$^{22}$

The 239 non-PPNG strains were typed at the Karolinska Institute. All other serological analyses were completed in Ottawa with serum samples and control strains sent from Sweden.

\section{MINIMUM INHIBITORY CONCENTRATION (MIC) MEASUREMENT, AUXOTYPING, AND PLASMID CONTENT ANALYSIS}

The MICs of penicillin, ampicillin, tetracycline, spectinomycin, erythromycin, cefoxitin, and cefuroxime for the isolates were measured by an agar dilution technique. ${ }^{27}$ Isolates were auxotyped using the method of Hendry and Stewart, ${ }^{2}$ as modified by Hendry, ${ }^{28}$ and their plasmid contents were analysed as described previously. ${ }^{29}$

\section{STATISTICAL ANALYSIS}

Associations between the variables (plasmid content, serovar, and auxotype) were examined using the likelihood ratio statistic that was estimated by the maximum likelihood method based on log linear models. ${ }^{30}$

\section{Results}

SEROGROUP AND SUSCEPTIBILITY TO ANTIMICROBIALS OF NON-PPNG STRAINS

Most $(160,67 \%)$ of the 239 non-PPNG strains were serologically typed as being serogroup WII/III, whereas $79(33 \%)$ were of the WI serogroup. Strains

TABLE I Monoclonal antibodies used in coagglutination tests to classify gonococcal isolates into serogroups WI and WII/ III and subgroup serogroups into serovars

\begin{tabular}{|c|c|c|c|c|c|c|c|c|c|c|c|c|c|c|}
\hline \multicolumn{7}{|c|}{$\begin{array}{l}\text { Serogroup WI strains tested with monoclonal } \\
\text { antibodies specific for protein } I A \text { : }\end{array}$} & \multicolumn{7}{|c|}{$\begin{array}{l}\text { WII/III strains tested with monoclonal } \\
\text { antibodies specific for protein IB: }\end{array}$} & \multirow{2}{*}{$\begin{array}{l}\text { Examples of } \\
\text { serovar } \\
\text { designation* }\end{array}$} \\
\hline $\begin{array}{l}6 G 9 \\
A f\end{array}$ & $\begin{array}{l}4 G 5 \\
\mathrm{Ae}\end{array}$ & $\begin{array}{l}2 F 12 \\
A d\end{array}$ & $\begin{array}{l}6 D 9 \\
\mathrm{Ag}\end{array}$ & $\begin{array}{l}5 C 2 \\
A k\end{array}$ & $\begin{array}{l}5 G 9 \\
A i\end{array}$ & $\begin{array}{l}5 D I \\
A h\end{array}$ & $\begin{array}{l}3 C 8 \\
B a\end{array}$ & $\begin{array}{l}2 D 6 \\
B c\end{array}$ & $\begin{array}{l}2 \mathrm{H7} \\
\mathrm{Be}\end{array}$ & $\begin{array}{l}2 G 2 \\
B g\end{array}$ & $\begin{array}{l}2 D 4 \\
B h\end{array}$ & $\begin{array}{l}3 B 10 \\
B j\end{array}$ & $\begin{array}{l}2 \mathrm{HI} \\
\mathrm{Bk}\end{array}$ & \\
\hline+ & $\begin{array}{l}+ \\
+ \\
+\end{array}$ & $\begin{array}{l}+ \\
+\end{array}$ & + & + & $\begin{array}{l}+ \\
+\end{array}$ & $\begin{array}{l}+ \\
+\end{array}$ & + & $\begin{array}{l}+ \\
+\end{array}$ & $\begin{array}{l}+ \\
+\end{array}$ & + & + & $\begin{array}{l}+ \\
+\end{array}$ & $\begin{array}{l}+ \\
+ \\
+\end{array}$ & $\begin{array}{l}\text { Afedgkih } \\
\text { Aedih } \\
\text { Ae } \\
\text { Bacejk } \\
\text { Bck } \\
\text { Beghjk }\end{array}$ \\
\hline
\end{tabular}

\footnotetext{
* = represents only a limited number of possible designations, depending on agglutination pattern.

$+=$ positive test reaction.
} 
TABLE II Minimum inhibitory concentration (MIC) of antibiotic related to serogroup

\begin{tabular}{|c|c|c|c|c|c|c|}
\hline \multirow[b]{2}{*}{ Antibiotic } & \multicolumn{3}{|c|}{ MICs (mg/l) for 79 WI serogroup strains } & \multicolumn{3}{|c|}{ MICs (mg/l) for $160 \mathrm{WII} / \mathrm{III}$ serogroup strains } \\
\hline & MIC 50\% & MIC $90 \%$ & Range of MICs & MIC 50\% & MIC $90 \%$ & Range of MICs \\
\hline $\begin{array}{l}\text { Penicillin } \\
\text { Ampicillin } \\
\text { Spectinomycin } \\
\text { Tetracycline } \\
\text { Erythromycin* } \\
\text { Cefoxitin } \\
\text { Cefuroxime }\end{array}$ & $\begin{array}{c}0.016 \\
0.032 \\
16.0 \\
0.25 \\
0.25 \\
0.25 \\
0.008\end{array}$ & $\begin{array}{l}0.25 \\
0.25 \\
16.0 \\
0.5 \\
0.5 \\
0.5 \\
0.063\end{array}$ & $\begin{array}{l}\geq 0.008-1.0 \\
\geq 0.008-1.0 \\
\geq 4.0-32.0 \\
\geq 0.032-1.0 \\
\geq 0.032-1.0 \\
\geq 0.008-2.0 \\
\geq 0.002-0.25\end{array}$ & $\begin{array}{l}0.25 \\
0.5 \\
16.0 \\
0.5 \\
0.25 \\
0.5 \\
0.125\end{array}$ & $\begin{array}{r}2 \cdot 0 \\
2 \cdot 0 \\
16 \cdot 0 \\
2.0 \\
2 \cdot 0 \\
4.0 \\
0.5\end{array}$ & $\begin{array}{l}\geq 0.008-32.0 \\
\geq 0.008-32.0 \\
\geq 4.0-32.0 \\
\geq 0.063-4.0 \\
\geq 0.032-4.0 \\
\geq 0.001-4.0 \\
\geq 0.001-2.0\end{array}$ \\
\hline
\end{tabular}

* MICs of erythromycin for $70 \mathrm{WI}$ isolates and $124 \mathrm{WII} / \mathrm{III}$ strains .

of the WI serogroup (table II) were generally more sensitive to antimicrobial agents than strains of serogroup WII/III. Except for susceptibility to spectinomycin, which was identical in both groups, the MIC $90 \%$ end points of penicillin, ampicillin, tetracycline, erythromycin, cefoxitin, and cefuroxime for WI strains were four to eight times lower than those for WII/III isolates. The MIC $50 \%$ end points of all antimicrobials except erythromycin and spectinomycin were also two to 16 times lower for WI strains than for WII/III strains. In addition, the upper range of MICs for WII/III strains was appreciably higher than for WI strains.

\section{SEROVAR, AUXOTYPE, AND SUSCEPTIBILITY TO ANTIMICROBIALS OF NON-PPNG STRAINS}

When serogroups were subtyped into serovars, the WI serogroup was notably less heterogeneous than the WII/III serogroup. WI strains were differentiated into eight serovars, and $65(82 \%)$ of the 79 strains typed were in serovar Aedgkih (table III). This serovar

TABLE III Serovars and auxotypes of 79 non PPNG WI isolates

\begin{tabular}{lrrrrrl}
\hline \multicolumn{7}{c}{ No with auxotype $\dagger$} \\
\cline { 3 - 7 } Serovars & No & OUH $^{-}$ & CUH & NR & Orn $^{-}$ & Other $¥$ \\
\hline Aedgkih & 65 & 39 & 8 & 6 & 2 & 10 \\
Aedgk & 4 & 1 & 1 & 1 & 1 & \\
Aedih & 3 & & & 3 & & 1 \\
Afedgkih & 2 & 1 & & 1 & & 1 \\
Ae & 2 & & & 1 & 1 & 1 \\
Others & 3 & 1 & & & 4 & 13 \\
Total & 79 & 42 & 9 & 11 & 4
\end{tabular}

One each of Adgk, Adgkih, Aed.

$\dagger$ Nutritional requirement: ornithine $\left(\mathrm{O}^{-}\right.$or $\left.\mathrm{Orn}^{-}\right)$, uracil $\left(\mathrm{U}^{-}\right)$, hypoxanthine $\left(\mathrm{H}^{-}\right)$, citrulline $\left(\mathrm{C}^{-}\right)$; proline ( $\mathrm{P}^{-}$or Pro $\left.{ }^{-}\right)$, or methionine $\left(\mathrm{M}^{-}\right.$or Meth $\left.^{-}\right)$; $\mathrm{NR}=$ non requiring, wild type, or prototrophic. $\ddagger$ PCUH $^{-}(1)$, POUH $^{-}(5), \mathrm{OH}^{-}(2)$, OUHM $^{-}(1), \mathrm{CUHM}^{-}(1), \mathrm{Pro}^{-}(2)$. proved to be remarkably sensitive to antimicrobials, particularly to $\beta$ lactam antibiotics, such as penicillin and cefuroxime (data not shown). A large percentage $(89-91 \%, 70-72)$ of these isolates were susceptible to $\leq 0.032 \mathrm{mg} / \mathrm{l}$ of penicillin, ampicillin, and cefuroxime; $54 \%$ (43) were sensitive to $\leq 0.125 \mathrm{mg} /$ of tetracycline.

The 79 serogroup WI strains comprised 10 auxotypes (table III). The ornithine, uracil, and hypoxanthine requiring ( $\left.\mathrm{OUH}^{-}\right)$auxotype predominated (in $42,53 \%$ ), followed by prototrophic (NR (wild or non-requiring)) strains (in 11, 14\%) and strains requiring citrulline, uracil and hypoxanthine $\left(\mathrm{CUH}^{-}\right)$(in nine, 11\%). The remaining 17 strains consisted of seven other auxotypes. Of the 65 strains of serovar Aedgkih, $39(60 \%)$ were $\mathrm{OUH}^{-}$auxotype and a further eight (12\%) were $\mathrm{CUH}^{-}$auxotype (table III). (As citrulline and ornithine are part of the arginine biosynthetic pathway, these two auxotypes may be classified as arginine, uracil, and hypoxanthine requiring $\left(\mathrm{AUH}^{-}\right)$strains).

The 160 strains of the WII/III serogroup were differentiated into 18 serovars (table IV) with 133 (83\%) comprising five serovars and with serovar Bacejk accounting for 71 (44\%) of the strains. In addition, WII/III isolates were typed into 15 auxotypes; five auxotypes comprised 147 (92\%) strains (table IV). The NR auxotype predominated (in $61,38 \%$ ) followed by $\mathrm{PCU}^{-}$in $45(28 \%)$. Of the 71 serovar Bacejk strains, 42 (59\%) were $\mathrm{PCU}^{-}$, and most (42. 93\%) of the $45 \mathrm{PCU}^{-}$strains were serovar Bacejk. The three other $\mathrm{PCU}^{-}$strains were typed as being serovars Baej, Bcegik, and Beghjk. Similarly, PCUH ${ }^{-}$strains were largely serovar Bacejk. The NR auxotype strains were differentiated into 18 serovars, but serovar Bcgk was exclusively NR.

Statistical analysis of the data about serovars and auxotypes in tables III and IV showed a significant degree of dependence between serovar and auxotype for WI non-PPNG strains $(p=0.02)$ and a highly significant degree of dependence between these same 
TABLE IV Serovars, auxotypes, and susceptibility to antimicrobials of 160 WII/II non-PPNG strains

\begin{tabular}{|c|c|c|c|c|c|c|c|c|c|c|c|c|}
\hline \multirow[b]{2}{*}{ Serovar } & \multirow[b]{2}{*}{ No } & \multicolumn{6}{|c|}{ No with auxotype $†$} & \multicolumn{5}{|c|}{ No $(\%)$ resistant $\S$ to: } \\
\hline & & $N R$ & $P C U$ & $\mathrm{Pro}^{-}$ & $\mathrm{Orn}^{-}$ & $\mathrm{PCUH}^{-}$ & Other $\ddagger$ & Penicillin & Ampicillin & Cefoxitin & Cefuroxime & Tetracycline \\
\hline $\begin{array}{l}\text { Bacejk } \\
\text { Bajk } \\
\text { Bacjk } \\
\text { Beghjk } \\
\text { Bcgk } \\
\text { Others* }\end{array}$ & $\begin{array}{r}71 \\
21 \\
18 \\
15 \\
8 \\
27\end{array}$ & $\begin{array}{r}10 \\
13 \\
3 \\
10 \\
8 \\
17\end{array}$ & $\begin{array}{l}1 \\
2\end{array}$ & $\begin{array}{r}8 \\
3 \\
13 \\
1 \\
\\
6\end{array}$ & $\begin{array}{l}2 \\
2 \\
1\end{array}$ & 1 & $\begin{array}{l}5 \\
3 \\
1 \\
2 \\
2\end{array}$ & $\begin{array}{r}14(78) \\
9(60) \\
6(75)\end{array}$ & $\begin{array}{r}11(52) \\
16(89) \\
9(60) \\
6(75)\end{array}$ & $\begin{array}{r}60(85) \\
15(71) \\
14(78) \\
12(80) \\
6(75) \\
19(70)\end{array}$ & $4(50)$ & $12(67)$ \\
\hline Total & 160 & 61 & 45 & 31 & 5 & 5 & 13 & & & & & \\
\hline
\end{tabular}

*Four Bak; three each of Bck, Bacek, and Baejk; two each of Bcej, Back, Bahjk, Baj, and Bcegjk; and one each of Bacej, Baehjk, Baej, and Bcgjk.

†See Table III for auxotype designations.

tOther auxotypes: $\mathrm{OUH}^{-}(1), \mathrm{PO}^{-}(2), \mathrm{POUH}^{-}(1), \mathrm{OH}^{-}(2), \mathrm{PCUM}^{-}(1), \mathrm{PH}^{-}(1), \mathrm{M}^{-}(1), \mathrm{PM}^{-}(1), \mathrm{CU}^{-}(2)$, and $\mathrm{PCUHM}^{-}(1)$.

$\S$ Resistance noted only if number $\geq 50 \%$. Resistance to penicillin, ampicillin, cefoxitin, and cefuroxime defined by MIC $0.5 \mathrm{mg} / \mathrm{l}$, to tetracycline by MIC $1.0 \mathrm{mg} / \mathrm{l}$.

variables for WII/III non-PPNG strains $(p=0.0001)$.

When we compared the serovar and auxotype variables related to susceptibility to antibiotics, it became evident that certain combinations of serovar and auxotype that seemed to be clonal had a wide range of MICs of certain antimicrobial agents. For example, PCU $^{-}$auxotype strains (serovar Bacejk) showed a wide range of MICs of penicillin (table V), and most isolates had reduced susceptibility (MIC 0.125-0.5 $\mathrm{mg} / \mathrm{l})$. On the other hand, the range of MICs of cefoxitin for Bacejk/PCU- isolates (which resembled that of tetracycline) was quite narrow. Similarily, NR strains of serovar Bacejk showed a wide range of MICs of penicillin and a narrow range of MICs of cefoxitin (which also resembled the range of MICs of tetracycline). In comparing serovar Aedgkih/OUH ${ }^{-}$ and $\mathrm{CUH}^{-}$strains, the $\mathrm{OUH}^{-}$strains were largely homogeneous, though a few isolates had higher MICs of penicillin; both groups showed narrow ranges of MICs of cefoxitin.

Just as certain serovars and auxotypes of the WI serogroup were responsible for the overall sensitivity to antimicrobial agents observed with this serogroup, certain serovars and auxotypes of the WII/III serogroup showed a high degree of resistance to antimicrobial agents (table IV). Group WII/III serovars Bacjk, Beghjk, and Bcgk mostly comprised resistant isolates (table IV). Over half of those isolates were resistant to penicillin, ampicillin, cefoxitin, and

TABLE V Minimum inhibitory concentrations (MICs) of penicillin and cefoxitin for several combinations of serovar and auxotype

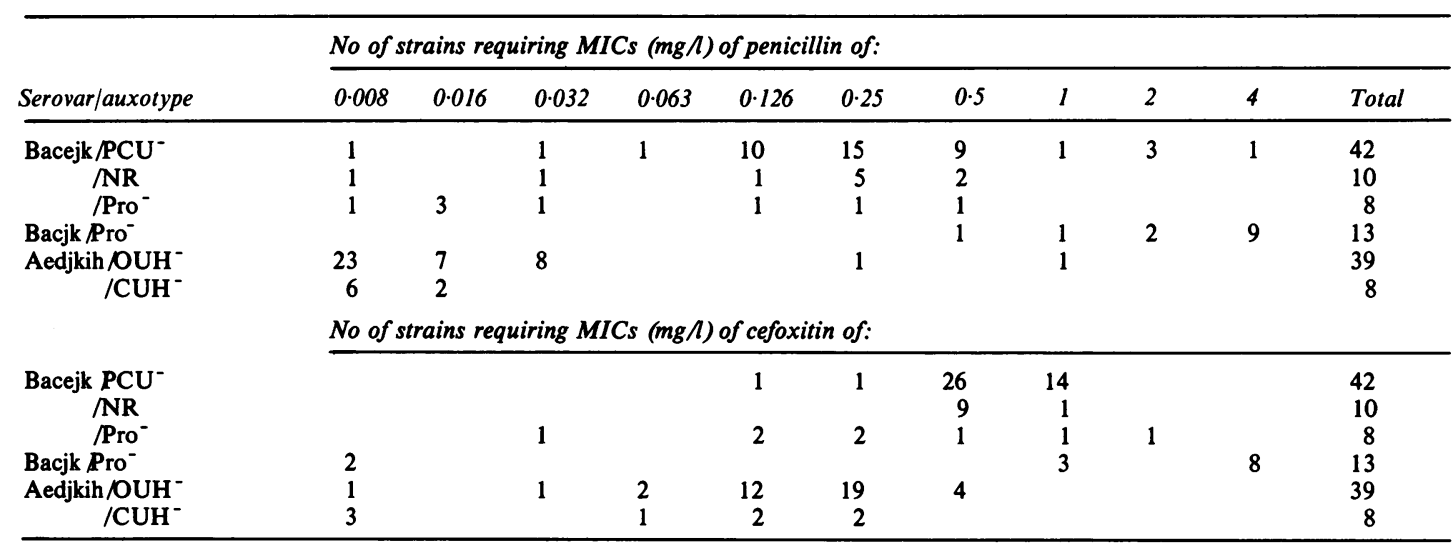

$\mathrm{NR}=$ non-requiring, wild type, or prototrophic auxotype; $\mathrm{Pro}^{-}=$requiring proline; $\mathrm{PCU}^{-}=$requiring proline, citrulline, and uracil, $\mathrm{OUH}^{-}$ $=$ requiring ornithine, uracil, and hypoxanthine; $\mathrm{CUH}^{-}=$requiring citrulline, uracil, and hypoxanthine. 
cefuroxime (MIC $\geq 0.5 \mathrm{mg} / \mathrm{l}$ ) and to $1.0 \mathrm{mg} / 1$ tetracycline. The WII/III serovars generally had reduced sensitivity to cefoxitin. The relation between serovar and MIC is clearly outlined when the MICs for Pro $^{-}$strains with either Bacejk or Bacjk serovars are compared (table V). Bacjk Pro $^{-}$strains were very resistant to penicillin and cefoxitin and the range of MICs was relatively narrow for penicillin. The range of MICs for Bacejk/Pro- strains, however, which were more sensitive, was wide.

\section{SEROVAR AND PLASMID CONTENT OF NON-PPNG AND} PPNG STRAINS

Most $(77,98 \%)$ of the 79 non-PPNG WI strains carried only the 2.6 megadalton cryptic plasmid (table VI); the other two WI strains harboured the 24.5 megadalton transfer plasmid as well. None of the WI strains was plasmid free. By contrast, only 107/160 (70\%) of the WII/III strains harboured the 2.6 megadalton plasmid and $15 \%(16 / 107)$ of these strains also carried a $24.5 \mathrm{Md}$ plasmid; $33 \%(53 / 160)$ carried no plasmids. The relation between carriage of the transfer plasmid and serogroup WII/III serovars was appreciable. Though most $(79 \%, 42 / 53)$ of the plasmid free strains were $\mathrm{PCU}^{-}$auxotype, it was notable that $49 / 53$ (93\%) plasmid free strains were serovar Bacejk irrespective of auxotype. The 24.5 megadalton transfer plasmid was present in strains that were either NR or Pro-, but these strains comprised nine serovars, seven of which were WII/III. Statistical analysis of the data in table VI showed a significantly high degree of dependence between the variables serovar and plasmid content $(p=0.001)$, and between plasmid content and auxotype $(p=0.001)$.

\section{ANALYSIS OF PPNG STRAINS}

PPNG strains comprised 14 serovars, five from the WI serogroup and nine from the WII/III serogroup (table VII). Though most of the PPNG strains characterised $(74 / 138,54 \%)$ were WI serogroup, 46 of these strains (of serovar $\mathrm{Ae}$ ) were associated with a single microepidemic. ${ }^{14}$ Of the $69 \mathrm{WII} / \mathrm{III}$ serogroup strains, 20 (of serovar Bacjk) had been collected from a microepidemic in Toronto and were distinguishable only by their serovar and unique plasmid content, ${ }^{31}$ and a further 19 strains (of serovar Bajk) had been isolated in Santiago, Chile and appeared to be homogeneous (in the absence of contact tracing data). ${ }^{32}$ Interestingly, strains contracted in Africa comprised 10 of the 14 serovars, whereas isolates contracted in Asia were represented by five serovars (Ae, Af, Back, Bajk, and Bacjk). Though the data are limited, certain serovars (Ae and Bacjk) of PPNG strains are found throughout the world, whereas others seem to be more associated with African (Beghjk, Bcegjk, Bcgjk, and Aedgkih) or Asian (Af) origins. Serovars Aedgkih harboured only African type penicillinase producing plasmids but these plasmids were associated with several auxotypes.

TABLE VI Relation between plasmid content, serovar, and auxotype of 239 non-PPNG strains

\begin{tabular}{|c|c|c|c|c|c|c|c|c|c|c|c|}
\hline \multirow{2}{*}{$\begin{array}{l}\text { Plasmid } \\
\text { content } \\
\text { (megadaltons) }\end{array}$} & \multirow[b]{2}{*}{ Serogroup } & \multirow[b]{2}{*}{ Serovar } & \multicolumn{9}{|c|}{ No with auxotype } \\
\hline & & & $N R$ & $P C U$ & $\mathrm{Pro}^{-}$ & $\mathrm{Orn}^{-}$ & PCUH & $O U H^{-}$ & $\mathrm{CUH}$ & Other & Total \\
\hline \multirow[t]{2}{*}{$2 \cdot 6$} & WI & $\begin{array}{l}\text { Aedgkih } \\
\text { Others }\end{array}$ & $\begin{array}{l}6 \\
4\end{array}$ & & & $\begin{array}{l}2 \\
2\end{array}$ & & $\begin{array}{r}39 \\
3\end{array}$ & $\begin{array}{l}8 \\
1\end{array}$ & $\begin{array}{r}10 \\
2\end{array}$ & $\begin{array}{l}65 \\
12\end{array}$ \\
\hline & WII III & $\begin{array}{l}\text { Bacejk } \\
\text { Bajk } \\
\text { Bacjk } \\
\text { Beghjk } \\
\text { Others }\end{array}$ & $\begin{array}{r}8 \\
11 \\
2 \\
10 \\
20\end{array}$ & & $\begin{array}{r}7 \\
1 \\
10 \\
1 \\
4\end{array}$ & $\begin{array}{l}2 \\
1\end{array}$ & $\begin{array}{l}1 \\
2 \\
1\end{array}$ & & & $\begin{array}{l}3 \\
2 \\
1 \\
2 \\
2\end{array}$ & $\begin{array}{l}21 \\
16 \\
14 \\
14 \\
26\end{array}$ \\
\hline \multirow[t]{2}{*}{$2 \cdot 6+24 \cdot 5$} & WI & $\begin{array}{l}\text { Aed } \\
\text { Aedih }\end{array}$ & 1 & & 1 & & & & & & $\begin{array}{l}1 \\
1\end{array}$ \\
\hline & WII/III & $\begin{array}{l}\text { Bacejk } \\
\text { Bajk } \\
\text { Bacjk } \\
\text { Bcgk } \\
\text { Others }\end{array}$ & $\begin{array}{l}2 \\
1 \\
4 \\
1\end{array}$ & & $\begin{array}{l}1 \\
2 \\
3 \\
2\end{array}$ & & & & & & $\begin{array}{l}1 \\
4 \\
4 \\
4 \\
3\end{array}$ \\
\hline No plasmids & WII/III & $\begin{array}{l}\text { Bacejk } \\
\text { Bajk } \\
\text { Beghjk } \\
\text { Others }\end{array}$ & 2 & $\begin{array}{r}42 \\
1 \\
2\end{array}$ & & & 3 & & & $\begin{array}{l}2 \\
1\end{array}$ & $\begin{array}{r}49 \\
1 \\
1 \\
2\end{array}$ \\
\hline
\end{tabular}

\footnotetext{
* Auxotype designations as for Tables III, IV, and V.
} 


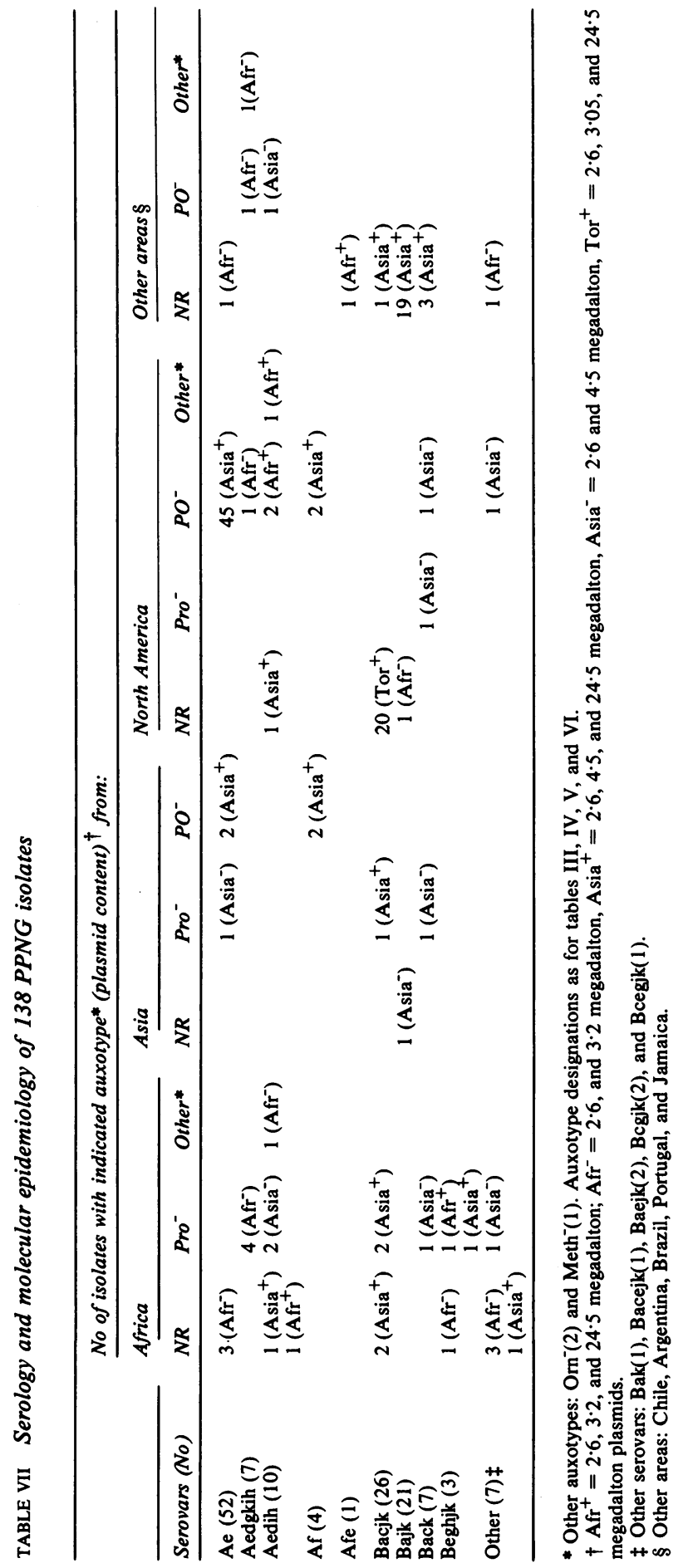




\section{Discussion}

The differentiation between gonococcal isolates based on combinations of plasmids, serogroups and serovars, and auxotypes has been a powerful tool for defining the epidemiology of outbreaks of infections with PPNG strains, ${ }^{513-16263133}$ in monitoring regional and temporal changes in the phenotype of the gonococcus, ${ }^{182633}$ and even in forensic studies. ${ }^{26}$ The characterisation of gonococci in this way not only permits the development of a global perspective on the spread of these strains, it also further enhances the biological characterisation of the strains regarding properties such as resistance to antibiotics ${ }^{182526}$ site of infection, ${ }^{34}$ expression of disease, ${ }^{9}$ and production of immunoglobulin A1 proteases. ${ }^{35}$

The study published here extends previous observations regarding the serology of gonococci from North America. ${ }^{9152633}$ Some $67 \%$ of isolates in this survey were serogroup WII/III. In a recent study from Winnipeg, Manitoba, $67 \%$ of 325 consecutive isolates were also WII/III. ${ }^{9}$ Thus in Canada, as in Thailand, Singapore, Korea, areas of Europe, the United States of America, Australia, and Africa, the predominant serogroup in non-PPNG strains was WII/III. ${ }^{15} 3336-39$ The most common WI serovar in Canada and other areas was Aedgkih. This serovar, as shown in the present study, was rarely associated with infections with PPNG strains. ${ }^{36}$ The same serovar was rarely detected in strains from Bangkok, Korea, Singapore, or Gabon. ${ }^{36}$ Thus, as Bygdeman has previously stated, North America may, like Europe, be one of the focuses for this serovar in non-PPNG strains. ${ }^{36}$ The greater diversity of WII/III serovars compared with WI serovars has also been observed by other workers. ${ }^{36}$ The serovar Bacejk, which was the most prevalent in the present collection of Canadian strains $(44 \%$ of WII/III strains), was one of the more prevalent serovars globally ${ }^{36}$ Though it was an uncommon serovar in South East Asia (1-3\%), it was fairly pre valent in Nordic countries (7-29\%) and Sydney, Australia (30\%). ${ }^{36}$

Differences in susceptibility to antimicrobial agents between serogroups have been noted previously. ${ }^{183641}$ WI serovars tend to be more sensitive to antibiotics, particularly to $\beta$ lactam antibiotics, than WII/III serovars. The present study shows that strains with serovars of the WII/III serogroup are heterogeneous in susceptibility to antimicrobials and that certain serovars correlated with resistance to antimicrobial agents. Differences between the serogroups were most pronounced for MICs of penicillin, ampicillin, and cefuroxime, whereas MICs of spectinomycin were identical for both groups. The MICs of tetracycline, erythromycin, and cefoxitin were slightly higher for WII/III serogroups. The overall sensitivity of the WI serogroup may be attributed to the predominance of serovar Aedgkih, which comprises the $\mathrm{AUH}^{-}$ auxotype, an auxotype known for its extreme sensitivity to penicillin. ${ }^{114}$ Serovar Bcgk strains were significantly resistant to antimicrobials. The homogeneity or heterogeneity of MICs for different auxotypes and serovars varied with each antibiotic (table V). Strains that are heterogeneous (such as $\mathrm{Pro}^{-} /$ Bacjk/cefoxitin MICs) but have disparate MICs might be further subtyped with the development of different monoclonal antibody reagents.

It is intriguing to speculate that serovar may be a more stable genetic property than auxotype. That is, older serovars may comprise several auxotypes, whereas the opposite may be true of newer serovars. For example, serovar Bacejk comprises over six auxotypes, whereas serovar Bcgk (possibly a newer serovar) includes only one auxotype. Furthermore, if auxotype were the more stable genetic property one would expect to see several serovars in one auxogroup. The reverse is true. For example, only $59 \%$ of Bacejk strains were $\mathrm{PCU}^{-}$, though $93 \%$ of the $\mathrm{PCU}^{-}$strains were of serovar Bacejk. PCU ${ }^{-}$is the most prevalent auxotype in Canada and is distinguished by the absence of the 2.6 megadalton plasmid that is characteristic of other gonococcal auxotypes. ${ }^{23}$ Interestingly, Brunham et al found that this auxotype was significantly associated with asymptomatic urethral infection in men. ${ }^{9}$

The presence of the 24.5 megadalton transfer plasmid in non-PPNG isolates correlated appreciably with the WII/III serovar. This explains why Asian type PPNG strains are more often found with the transfer plasmid, as strains endogenous in Africa tend to be serogroup WI and free of transfer plasmids.

The importation of PPNG strains into Canada is readily discernable when serovars are analysed, as none of the most prevalent non-PPNG serovars, except Bacjk, were also the most prevalent PPNG serovars. In addition, WI serovars were more prevalent than WII/III serovars in the PPNG strains characterised. Serovar Ae, which was the most prevalent serovar in PPNG strains in this study, has also been detected in Sweden and Holland. ${ }^{13} 36$ Though the PPNG strains with this serovar that were isolated in Sweden had been imported from "Africa", the serovar had been imported into Canada from around the world. Furthermore, serovar Ae strains that harboured the cryptic plasmid, the 3.2 megadalton penicillinase producing plasmid, and the transfer plasmid have been characterised in Amsterdam, though they were not isolated in the present study. ${ }^{36}$

The serological analysis of PPNG strains, coupled with auxotyping and plasmid content analysis, has been highly efficacious in tracing the intercontinental spread of PPNG strains. Several workers have observed 
that serogroup WI PPNG strains that were typed auxanographically as NR, $\mathrm{Pro}^{-}$, or $\mathrm{Arg}^{-}$could be traced to African origins, whereas certain WII/III serovars were characteristic of PPNG strains isolated on the Asian mainland. ${ }^{151836-40}$ Studies of the prevalence of PPNG strains in Africa, which have shown WII/III strains with 4.5 megadalton penicillinase producing (Asian type) plasmid, have generally attributed their presence to the importation of these strains from Thailand, Singapore, or Hong Kong. ${ }^{16}$ Conversely, PPNG strains with WI serovars were considered to be endogenous. ${ }^{1636}$ The present study indicates that a diversity of serovars have been exported from Africa. Serovar Aedgkih strains that are Pro $^{-}$auxotype and carry the cryptic plasmid and the 3.2 megadalton penicillinase producing plasmid (African type) are undoubtedly African in origin, as has been observed by other workers. ${ }^{16} 36$ The present study documents the presence of this combination of serovars and plasmids in an Orn- strain isolated in Argentina and in $\mathrm{Pro}^{-} \mathrm{Orn}^{-}$strains imported into Canada from Jamaica and the United States of America. Data from the present study also support the hypothesis that PPNG strains that are serovar Ae, NR auxotype, and harbour the cryptic African type plasmid probably originated in Africa, whereas isolates of the Ae serovar and $\mathrm{Pro}^{-}$or $\mathrm{Pro}^{-} \mathrm{Orn}^{-}$ auxotype that harbour Asian type penicillinase producing plasmids with $\left(\mathrm{Asia}^{+}\right)$or without (Asia-) the transfer plasmid may have originated in South East Asia (Singapore, Malaysia, or Hong Kong). An Asia ${ }^{+}$ strain was responsible for a major epidemic of infections with PPNG strains in Canada. ${ }^{14}$

Serovar Af PPNG strains have not been observed outside Canada, though two of the strains had been imported from the Phillipines and Malaysia. ${ }^{14}$ Af nonPPNG strains have, however, been isolated in Singapore. ${ }^{36}$ Similarly, though serovar Afe/Pro $/$ $\mathrm{Asia}^{+}$strains have been isolated in Amsterdam, ${ }^{36}$ the Afe $/ \mathrm{NR} / \mathrm{Africa}^{+}$strain characterised in the present study was imported into Canada from Portugal. Several PPNG serovars that have been associated with Asian origins include Back, Bak, and Bcegjk ${ }^{36}$ Though PPNG strains of these serovars were imported into Canada from Africa, their origins probably rest in the Far East. The PPNG strains recovered from Chile

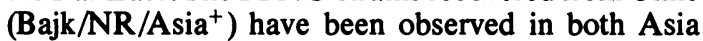
and Africa. Similarly three PPNG strains from Argentina (Bac/NR/Asia ${ }^{+}$) have also been observed in Asia. ${ }^{36}$

In conclusion, this study has shown that certain WII/III serovars correlate highly with resistance to antibiotics, that the presence or absence of the cryptic and transfer plasmids correlate highly with both serovar and auxotype, and that the global distribution of PPNG strains can be characterised, in part, by analysing serovar, auxotype, and plasmid content.

We thank Marielle Pauzé, Maria Carballo (Ottawa), and Christine Gillenius (Stockholm) for their technical help. We also thank W Tostowaryk (Laboratory Centre for Disease Control (LCDC), Ottawa) for completing the relevant statistical analyses, and Dr G Bezanson (LCDC) for his critical reading of the manuscript.

\section{References}

1. Catlin BW. Nutritional profiles of Neisseria gonorrhoeae, Neisseria meningitidis and Neisseria lactamica in chemically defined media and the use of growth requirements for gonococcal typing. J Infect Dis 1973;128:178-94.

2. Hendry AT, Stewart IO. Auxanographic grouping and typing of Neisseria gonorrhoeae. Can J Microbiol 1979;25:512-21.

3. Dillon JR, Pauzé M. Relationship between plasmid content and auxotype in Neisseria gonorrhoeae isolates. Infect Immun 1981;33:625-8.

4. Klingeren van B, Ansink-Schipper MC, Dessens-Kroon M, Verheuvel M. Relationship between auxotype, plasmid pattern and susceptibility to antibiotics in penicillinase-producing Neisseria gonorrhoeae. J Antimicrob Chemother 1985; 16:143-7.

5. Falk ES, Danielsson D, Bjorvator B, et al. Phenotypic and genetic characterization of penicillinase-producing strains of Neisseria gonorrhoeae. Acta Pathol Microbiol Immunol Scand [B] 1985;93:91-7.

6. Ansink-Schipper MC. Auxanographic typing of Neisseria gonorrhoeae isolated in the Netherlands. Amsterdam: University of Amsterdam, 1985. Ph D thesis.

7. Nobel RC, Miller BR. Auxotypes and antimicrobial susceptibilities of Neisseria gonorrhoeae in black and white patients. British Journal of Venereal Diseases 1980;56:26-30.

8. Knapp JS, Holmes KK. Disseminated gonococcal infections caused by Neisseria gonorrhoeae with unique nutritional requirements. $J$ Infect Dis 1975;132:204-8.

9. Brunham RC, Plummer F, Slaney L, Rand F, DeWitt W. Correlation of auxotype and protein I type with expression of disease due to Neisseria gonorrhoeae. $J$ Infect Dis 1985; 152:339-43.

10. Stewart IO, Hendry AT. Association between the auxogroup of Neisseria gonorrhoeae and the minimum inhibitory concentration of penicillin. Sex Transm Dis 1978;6:247-52.

11. Dillon JR, Pauzé M. Resistance to antimicrobial agents. What next for Neisseria gonorrhoeae? Sex Transm Dis 1984;11 suppl:353-9.

12. Buisson Y, Riou JY, Labidi A, Arborio M, Guibourdenche $\mathbf{M}$. A propos des gonoccoques producteurs de bêta-lactamase isolés à Dakar. Sensibilité à divers antibiotiques, auxotype et contenu plasmidique. Pathol Biol (Paris) 1985;33:550-3.

13. Ramstedt KM, Hallhagen GJ, Bygdeman SM, et al. Serologic classification and contact-tracing in the control of microepidemics of $\beta$-lactamase-producing Neisseria gonorrhoeae. Sex Transm Dis 1985;12:209-14.

14. Dillon JR, Pauzé M, Gould R, Sutherland R, Romanowski B. Penicillinase producing Neisseria gonorrhoeae with pro ${ }^{-}$orn $^{-}$, WI , Asia ${ }^{+}$phenotype. Lancet 1986; :103-4.

15. Handsfield HH,Sandström EG ,Knapp JS, et al. Epidemiology of penicillinase-producing Neisseria gonorrhoeae infections. Analysis by auxotyping and serogrouping. $N$ Engl $J$ Med 1982;306:950-4.

16. Plummer FA, D'Costa LJ, Nsanze H, et al. Development of endemic penicillinase producing Neisseria gonorrhoeae in Kenya. In: Schoolnik GK, Brooks G, Falkow JS, Knapp JS, 
McCutchan A, Morse S, eds. The pathogenic neisseriae. Proceedings of the fourth international symposium. Washington DC : American Society of Microbiology, 1985:101-6.

17. Sandström E, Danielsson D. Serology of Neisseria gonorrhoeae. Classification with co-agglutination.Acta Pathol Microbiol Scand [B] 1980;88:27-38.

18. Bygdeman S. Serological classficiation of Neisseria gonorrhoeae. Relation to antibiotic susceptibility and auxotypes. Epidemiological applications. Stockholm: Karolinska Institute, 1981. Ph D thesis.

19. Sandström EG, Knapp JS, Buchanan TM. Serology of Neisseria gonorrhoeae: W antigen serogrouping by coagglutination and protein I serotyping by enzyme-linked immunosorbent assay both detect protein 1 antigens. Infect Immun 1982;35:229-39.

20. Kronvall G. A rapid slide agglutination method for typing pneumococci by means of specific antibody absorbed to protein A containing staphylococci. J Med Microbiol 1973;6:187 90.

21. Tam MR, Buchanan TM, Sandström EG, et al. Serological classification of Neisseria gonorrhoeae with monoclonal antibodies. Infect Immun 1982;36:1042-53.

22. Knapp JS, Bygdeman S, Sandström E, Holmes KK. Nomenclature for the serological classification of Neisseria gonorrhoeae. In: Schoolnik GK, Brooks G, Falkow JS, Knapp JS, McCutchan A, Morse A, eds. The pathogenic neisseria. Proceedings of the fourth international symposium. Washington, DC: American Society of Microbiology, 1985:4-5.

23. Bydgeman S, Danielsson D, Sandström E. Gonococcal W serogroups in Scandinavia. A study with polyclonal and monoclonal antibodies. Acta Pathol Microbiol Scand [B] 1983;91:239-305.

24. Knapp JS, Tam MR, Nowinski RC, Holmes KK, Sandström EG. Serological classification of Neisseria gonorrhoeae with use of monoclonal antibodies to gonococcal outer membrane protein 1.J Infect Dis 1984;150:44-8.

25. Danielsson D, Bygdeman A, Kallings I. Epidemiology of gonorrhoeae. Serogroup , antibiotic susceptibility and auxotype patterns of consecutive gonococcal isolates from ten different areas of Sweden. Scand J Infect Dis 1983;15:33-42.

26. Knapp JS, Sandström EG, Holmes KK. Overview of epidemiological and clinical applications of auxotype/serovar classification of Neisseria gonorrhoeae. In: Schoolnick GK, Brooks G, Falkow JS, Knapp JS, McCutchan A, Morse A, eds. The pathogenic neisseriae. Proceedings of the fourth international symposium Washington, DC: American Society of Microbiology, 1985:6-12.

27. Dillon JR. Laboratory methods for Neisseria gonorrhoeae MIC, auxotype, screening for PPNG). Ottawa, Canada: National Health and Welfare, 1983 (catalogue No H47-58/ 1983E).

28. Hendry AT. Growth responses of Neisseria gonorrhoeae auxotypes to required amino acids and bases in liquid medium. Can J Microbiol 1983;29:1309-13.

29. Dillon JR, Pauzé M, Yeung K H.Molecular and epidemiological analysis of penicillinase-producing strains of Neisseria gonorrhoeae isolated in Canada 1976-84: evaluation of new auxotypes and $\beta$-lactamase-encoding plasmids. Genitourin
Med 1986;62:151-7.

30. Fienberg SE. The analysis of cross-classified categorical data. 2nd ed. Cambridge, Massachusetts: MIT Press, 1977.

31. Yeung K-H, Dillon JR, Pauzé M, Wallace E. Outbreak of PPNG caused by a novel 3.05 Md penicillinase-producing plasmid (Toronto-type) related to the Asian-type plasmid. J Infect Dis 1986;153:1162-5.

32. Moreno JG, Dillon JR, Arroyave R, et al. Identification of penicillinase-producing Neisseria gonorrhoeae (PPNG) in Chile during clinical and microbiological investigations of gonococcal susceptibility to antimicrobial agents. Genitourin Med 1987;63:6-12.

33. Whittington WL, Vernon A, Biddle JW, et al. Serological classification of Neisseria gonorrhoeae: uses at the community level. In: Schoolnik GK, Brooks G, Falkow JS, Knapp JS, McCutchan A, Morse A, eds. The pathogenic neisseriae. Proceedings of the fourth international symposium. Washington, DC: American Society of Microbiology, 1985:205.

34. Reid KG, Young H, McMillan A. Serogrouping of Neisseria gonorrhoeae: correlation with site of infection. In: Schoolnik GK, Brooks G, Falkow JS, Knapp JS, McCutchan A, Morse A, eds. The pathogenic neisseriae. Proceedings of the fourth international symposium. Washington, DC: American Society of Microbiology, 1985:66-70.

35. Mulks MH, Knapp JS. Immunoglobulin Al protease types of Neisseria gonorrhoeae. In: Schoolnik GK, Brooks G, Falkow JS, Knapp JS, McCutchan A, Morse A, eds. The pathogenic neisseriae. Proceedings of the fourth international symposium. Washington, DC: American Society of Microbiology, 1985:51-6.

36. Bygdeman SM. Polyclonal and monoclonal antibodies applied to the epidemiology of gonococcal infection. In: Young $\mathbf{H}$, McMillan A, eds. Immunological diagnosis of sexually transmitted diseases. New York: Marcel Decker, 1987:117-65.

37. Odugbemi TO, Brown ST, Biddle J, et al. Plasmid profile, serogrouping, and auxotyping of Neisseria gonorrhoeae isolates from Africa. British Journal of Venereal Diseases 1983;59: 41-3.

38. Odugbemi TO, Whittington WL, DeWitt W, et al. Epidemiological characterisation of Neisseria gonorrhoeae isolates from the Far East. British Journal of Venereal Diseases 1983;59:285-8.

39. Yvert F, Frost E, Guibourdenche M, Riou JY, Ivanoff B. Auxotypes and serogroups of penicillinase producing and nonproducing strains of Neisseria gonorrhoeae isolated in Franceville, Gabon. Genitourin Med 1985;61:99-102.

40. Bygdeman S, Kallings I, Danielsson D. Serogrouping and auxotyping for epidemiological study of beta-lactamaseproducing Neisseria gonorrhoeae strains isolated in Sweden. Acta Derm Venereol (Stockholm) 1981;61:329-34.

41. Bydgeman S, Mårdh P-A, Sandström E. Susceptibility of Neisseria gonorrhoeae to rifampicin and thiamphenicol. Correlation to protein 1 antigenic determinants. Sex Transm Dis 1984;11:366-70.

42. Knapp JS, Holmes KK. Disseminated gonococcal infections caused by Neisseria gonorrhoeae with unique nutritional requirements. J Infect Dis 1975;132:204-8. 